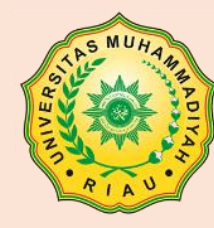

F A K U L T A S EKONOMI DAN BISNIS

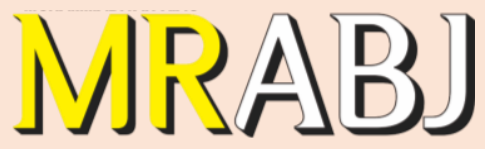

Muhammadiyah Riau Accounting and Business Journal journal homepage: http://ejurnal.umri.ac.id/index.php/MRABJ

\title{
APAKAH KEJUJURAN PENGELOLA ANGGARAN DAN JENIS PENGHARGAAN MEMPENGARUHI SENJANGAN ANGGARAN?
}

\author{
Tio Rasmi Simatupang
}

Faculty of Economic and Business, Universitas Muhammadiyah Riau, Indonesia

Email: tiorasmisiburian@gmail.com

\section{A R T I C L E I N F O}

Article History:

Received: 05 July 2021

Revised: 13 October 2021

Accepted: 29 October 2021

Keywords:

Senjangan Anggaran;

Kejujuran Pengelola Anggaran;

Penghargaan Moneter;

Penghargaan Non Moneter

\begin{abstract}
A B S T R A C T
Penelitian ini bertujuan untuk mengetahui pengaruh kejujuran pengelola anggaran, penghargaan moneter dan non moneter terhadap senjangan anggaran. Penelitian ini menggunakan metode kuantitatif dan sumber data yang digunakan dalam penelitian ini menggunakan data primer yang diperoleh dari kuesioner. Sampel yang digunakan sebanyak 51 responden dari perusahaan distributor yang diperoleh dengan metode purposive sampling. Uji hipotesis menggunakkan analisis regresi berganda. Hasil penelitian menunjukkan bahwa kejujuran pengelola anggaran berpengaruh signifikan terhadap senjangan anggaran. Sementara itu, penghargaan moneter dan non moneter berpengaruh signifikan terhadap senjangan anggaran. Secara simultan seluruh variabel independen dalam penelitian ini yaitu kejujuran pengelola anggaran, penghargaan moneter dan non moneter berpengaruh signifikan terhadap senjangan anggaran. Namun, ketika dilakukan uji terpisah pada penghargaan moneter dan non moneter terhadap senjangan anggaran hasil penelitian menunjukkan bahwa pengahargaan moneter berpengaruh terhadap senjangan anggaran sedangkan pengahargaan non moneter tidak berpengaruh terhadap senjangan anggaran. Penelitian ini memberikan implikasi bahwa organisasi harus selalu meningkatkan kejujuran dalam pengelolaan anggaran dan memberikan penghargaan (reward) apabila karyawannya dapat mencapai target yang diharapkan.
\end{abstract}

\section{Pendahuluan}

Persaingan antar organisasi semakin ketat sehingga suatu perusahaan atau pelaku bisnis memerlukan sebuah isntrumen yang dapat digunakan untuk mencapai tujuan. Salah satu bentuk tindakan yang dapat dilakukan agar tujuan yang ditetapkan dapat dicapai adalah dengan membuat sebuah perencanaan dan pengendalian.

Permasalahan yang mungkin terjadi didalam penyususnan anggaran adalah timbulnya senjangan anggaran. Senjangan anggaran dapat menyebabkan masalah bagi perusahaan, jika pengaloksian sumber daya yang tidak efisien maka anggaran yang ditetapkan menjadi tidak efektif, serta tidak akan berfungsi dengan baik karena anggaran yang disesuaikan tidak mencerminkan kemampuan manajer yang sebenarnya. Adanya kesempatan untuk mementingkan diri sendiri dalam penyusunan anggaran akan menyebabkan terjadinya kesenjangan, dimana individu cenderung berpikir secara ekonomi dan memotivasi semata-mata untuk kepentingan sendiri. Jika terus terjadinya senjangan anggaran perusahaan akan memiliki kinerja yang tidak baik atau maksimal. Hal tersebut akan memicu perusahaan tidak dapat 
bersaing secara sehat dengan perusahaan kompetitor lainnya, sehingga perusahaan akan mengalami suatu kerugian. Menurut Supanto (2010) salah satu kondisi yang menyebabkan terjadinya senjangan anggaran yaitu dengan adanya informasi asimetri, dimana informasi yang dimiliki oleh bawahan lebih banyak dibandingkan informasi yang dimiliki atasannya.

Senjangan anggaran merupakan selisih jumlah yang dianggarkan dengan jumlah yang direalisasikan. Senjangan anggaran dilakukan oleh bawahan dengan menyajikan anggaran dengan tingkat kesulitan yang rendah agar mudah dicapai dan kesenjangan ini cenderung dilakukan oleh bawahan karena mengetahui bahwa kinerja mereka diukur berdasarkan tingkat pencapaian anggaran yang telah ditetapkan bersama (Hapsari, 2016). Terjadinya senjangan anggaran adalah ketika bawahan berusaha menciptakan slack dalam anggaran perusahaan selama proses penyusunan anggaran dengan memasukkan perkiraan atau peramalan yang biasa terhadap kondisi operasi perusahaan di masa mendatang. Slack anggaran timbul apabila karyawan sengaja menetapkan pendapatan terlalu rendah atau menetapkan biaya terlalu tinggi. Setiap tindakan tersebut menyebabkan tingginya kemungkinan untuk mencapai target anggaran yang dibuat dan menurunkan resiko yang dihadapinya (Bitlinandas, 2018).

Ketika karyawan mengetahui adanya tindakan yang tidak sesuai dengan kebijakan perusahaan, karyawan akan melakukan pengaduan kepada pihak yang berwenang untuk mengambil keputusan sebagai tindakan media penyampaian informasi kepada atasan. Meski dalam melakukan pengaduan tersebut diikuti oleh ketakutan apabila di masa yang akan datang tindakan yang diambil justru memberikan efek buruk bagi dirinya seperti ancaman, intimidasi oleh rekan (Rahmawati dan Aryani, 2019).

Lau dan Enggleton (2003) dalam Rahmawati dan Aryani (2019) juga menemukan bahwa rekan yang jujur lebih menurunkan potensi senjangan anggaran daripada rekan yang tidak jujur. Sementara itu ketika karyawan mengetahui adanya tindakan kecurangan oleh rekan sekerjanya, karyawan tersebut akan berpikir ulang untuk melaporkannya. Konsep kejujuran sebelumnya telah dilakukan bahwa adanya pengaruh kejujuran atas perilaku karyawan dalam menyusun anggaran kepada pimpinan. Banyak karyawan enggan melaporkan meski dirinya mengetahui atas tindakan yang menyimpang dalam perusahaan, karyawan lebih memilih untuk diam atau memilih untuk tidak jujur daripada mendapatkan dampak negatif atas perilaku yang telah dilakukannya. Kejujuran dipilih sebagai pencegahan senjangan anggaran karena kejujuran ikut terlibat pada saat penentuan target anggaran. Rekan yang jujur dalam penentuan target anggaran akan memengaruhi rekan lain untuk bertindak jujur sehingga dapat menurunkan potensi senjangan anggaran. Individu memiliki pilihan untuk berperilaku secara jujur. Namun, individu juga dapat berperilaku tidak jujur akibat adanya kesempatan atau keputusan perilaku individu lain, seperti pimpinan atau rekan kerjanya (Valle dan Ploner, 2017).

Dalam hal ini, penghargaan yang diberikan kepada karyawan dapat berupa penghargaan moneter dan non moneter. Penghargaan diberikan sebagai motivasi karyawan atas pekerjaan yang dilakukannya. System penganggaran jika dihubungkan dengan system penghargaan akan berpotensi meningkatkan senjangan anggaran. Semakin menarik persepsi karyawan atas penghargaan yang diberikan, hal tersebut dapat memicu kinerja karyawan yang meningkat. Insentif yang diharapkan tidak selalu berupa uang melainkan seperti penghargaan, apresiasi, pemberian fasilitas, dan sebagainya. Karakteristik seseorang yang tidak memiliki orientasi terhadap uang, cenderung mencari insentif non moneter sebagai bentuk apresiasi atas pekerjaannya, sedangkan karakteristik seseorang yang berorientasi terhadap uang akan justeru memilih penghargaan berupa uang (Setyobudi et al., 2017).

Ketika karyawan mengetahui adanya tindakan yang tidak sesuai dengan kebijakan perusahaan, karyawan akan melakukan pengaduan kepada pihak yang berwenang untuk mengambil keputusan sebagai tindakan media penyampaian informasi kepada atasan. Meski dalam melakukan pengaduan tersebut diikuti oleh ketakutan apabila di masa yang akan datang tindakan yang diambil justru 
memberikan efek buruk bagi dirinya seperti ancaman, intimidasi oleh rekan. Sementara itu ketika karyawan mengetahui adanya tindakan kecurangan oleh rekan sekerjanya, karyawan tersebut akan berpikir ulang untuk melaporkannya.

Kondisi inilah yang memungkinkan adanya dilema etis oleh karyawan tersebut untuk melakukan tindakan pengaduan. Konsep kejujuran sebelumnya telah dilakukan dalam lingkup akuntansi manajemen yang menunjukkan bahwa adanya pengaruh kejujuran atas perilaku karyawan dalam menyusun anggaran kepada pimpinan. Banyak karyawan enggan melaporkan meski dirinya mengetahui atas tindakan yang menyimpang dalam perusahaan, karyawan lebih memilih untuk diam atau memilih untuk tidak jujur daripada mendapatkan dampak negatif atas perilaku yang telah dilakukannya.

Berdasarkan penelitian terdahulu menyatakan bahwa senjangan anggaran lebih besar terjadi akibat pengaruh rekan yang tidak jujur daripada rekan yang jujur di bawah kondisi asimetri informasi (Rahmawati dan Aryani, 2019). Namun, penghargaan non moneter tidak memengaruhi hubungan kedua variabel tersebut. Yandriyan (2019) menunjukkan bahwa partisipasi anggaran, komitmen organisasi, kapasitas individu, dan kejelasan sasaran anggaran berpengaruh negatif dan signifikan terhadap kesenjangan anggaran. Agustina (2018) menyatakan bahwa obedience pressure berpengaruh positif dan signifikan terhadap budgetary slack, dan organizational commitment berpengaruh negatif dan signifikan terhadap budgetary slack. Analisis variabel moderating dengan pendekatan nilai selisih mutlak menunjukkan bahwa pertimbangan etika mampu memoderasi obedience pressure dan organizational commitment terhadap penciptaan budgetary slack.

Biantara dan Putri (2014) menunjukkan bahwa variabel kejelasan sasaran anggaran berpengaruh positif pada senjangan anggaran, variabel etika, dan kepercayaan diri berpengaruh negatif pada senjangan anggaran. Afiani (2010) menunjukkan bahwa hipotesis di awal penelitian diterima karena partisipasi anggaran berpengaruh terhadap senjangan anggaran dan hal tersebut juga berlaku pada interaksi antara variabel bebas dan variabel terikat. Ketika, partisipasi anggaran, penekanan anggaran dan asimetri informasi tinggi maka senjangan anggaran juga akan tinggi. Dan menurut penelitian (Tjandra, 2008) menyatakan partisipasi dalam penyusunan anggaran berpengaruh signifikan terhadap kinerja namun tidak ditemukan pengaruh interaksi antara partisipasi dalam penyusunan anggaran dan reward terhadap kinerja manajerial.

Penelitian ini menguji kembali penelitian yang telah dilakukan oleh peneliti (Rahmawati dan Aryani, 2019) dengan perbedaan objek penelitian pada perusahaan PT. Riau Abdi Sentosa dan CV. Bintang Terang yang ada di kota Pekanbaru. Dengan perbedaan kultur pada organisasi dapat menjelaskan bagaimana variabel $\mathrm{x}$ berpengaruh terhadap variabel $\mathrm{y}$. Tujuan dari penelitian ini adalah untuk mengetahui pengaruh kejujuran pengelola anggaran terhadap senjangan anggaran dan untuk mengetahui penghargaan moneter dan non moneter terhadap senjangan anggaran.

\section{Tinjauan Pustaka dan Pengembangan Hipotesis}

\subsection{Teori Keagenan dan Senjangan Anggaran}

Teori keagenan pertama kali dikemukakan oleh Jensen \& Meckling (1976) dimana terjadi perbedaan kepentingan antara manajemen dan kepentingan pemegang saham yang seringkali bertentangan, yang bisa menyebabkan terjadinya konflik antara principal dengan agent (Azmi et al., 2021). Agency theory muncul karena pemisahan kepemilikan perusahaan dengan pengelolaan khususnya pada perusahaan-perusahaan besar yang modern, dimana satu atau lebih individu (pemilik) menggaji individu lain (agen) untuk bertindak atas namanya dan mendelegasikan kekuasaan untuk membuat keputusan terhadap agen (Brigham \& Gapenski, 1996). Praktik senjangan anggaran dalam persprektif teori agensi dipengaruhi oleh adanya konflik kepentingan antara agen (manajemen) dengan prinsipal yang timbul ketika setiap pihak berusaha untuk mencapai atau mempertahankan tingkat kemakmuran yang dikehendakinya. Dalam agency theory apabila atasan mempercayakan wewenangnya kepada bawahan untuk melakukan suatu tugas atau 
otoritas untuk membuat keputusan. Jika bawahan (agent) yang terlibat dalam proses penyusunan anggaran mempunyai informasi khusus tentang kondisi lokal, akan memungkinkan bawahan memberikan informasi yang dimilikinya untuk membantu kepentingan perusahaan. Namun, sering keinginan atasan tidak sama dengan bawahan sehingga menimbulkan konflik diantara mereka. Misalnya, hal ini dapat terjadi jika perusahaan memberikan penghargaan (rewards) kepada bawahan didasarkan pada pencapaian anggaran merupakan suatu kebijakan yang tepat. Sering kali bahawan memberikan informasi yang menyimpang agar anggaran mudah dicapai dan mendapatkan penghargaan (rewars) dengan mudah.

Anggaran merupakan alat manajemen yang penting untuk mengkomunikasikan rencanarencana manajemen dalam suatu organisasi, mengalokasikan sumber daya dan mengkoordinasikan aktivitas serta tidak menutup kemungkinan bahwa partisipasi anggaran tersebut dapat menimbulkan kesenjangan anggaran (Sugianto et al., 2020). Senjangan anggaran (budgetary slack) adalah perbedaan antara jumlah anggaran yang diajukan oleh bawahan dengan jumlah estimasi terbaik yang diberikan oleh organisasi. Estimasi yang dimaksud adalah anggaran yang terjadi dan sesuai dengan kemampuan terbaik organisasi. Slack merupakan selisih antara sumber daya yang diperlukan secara efisien untuk menyelesaikan suatu tugas dan jumlah sumber daya yang diperlukan lebih besar sehingga pegawai yang terlibat dalam penyusunan anggaran menciptakan slack agar lebih mudah dalam pencapaian targetnya (Yandriyan, 2019). Oksanda (2015) menyebutkan alasan utama manajer melakukan budgetary slack, yaitu, orang - orang selalu percaya bahwa hasil pekerjaan mereka akan terlihat bagus di mata atasan jika mereka dapat mencapai anggarannya, budgetary slack selalu digunakan untuk mengatasi kondisi tidak pasti, dan rencana anggaran selalu dipotong dalam proses pengalokasian sumber daya.

\subsection{Kejujuran Pengelola Anggaran}

Kejujuran adalah sifat jujur, ketulusan hati, atau keterbukaan dari jiwa yang bersih yang dinyatakan dalam suatu pernyataan, perbuatan serta perkataan sebagai suatu perbuatan maupun pengakuan yang sesuai dengan fakta yang ada. Kejujuran seorang pengelola anggaran dalam sangatlah penting karena perilaku kejujuran berpengaruh dalam penyusunan dan pelaksanaan anggaran. Perilaku etika kejujuran seorang pengelola anggaran merupakan kondisi dasar bagaimana karyawan bertindak secara etis, mengambil keputusan serta prinsip-prinsip moral yang dimiliki menjadi pegangan bagi karyawan dalam bertindak dan menjadi tolak ukur dalam menilai baik atau buruknya suatu tindakan sehingga dapat menuntut adanya keterbukaan dan kebenaran dalam suatu kejujuran. Rahmawati dan Aryani (2019) menyatakan kejujuran dipilih sebagai pengendalian informal pencegahan senjangan anggaran karena kejujuran ikut terlibat pada saat penentuan target anggaran. Rekan yang jujur dalam penentuan target anggaran akan mempengaruhi rekan lain untuk bertindak jujur sehingga dapat menurunkan potensi senjangan anggaran. Berdasarkan uraian di atas, Jika pelaku bisnis yang jujur selalu bersedia memberi keterangan maka perilaku yang dimiliki oleh bawahan dalam proses penganggaran patuh terhadap peraturan, artinya semakin adanya kejujuran yang dimiliki individu semakin kecil pula terjadinya slack. Individu memiliki pilihan untuk berperilaku secara jujur, namun individu juga daoat berperilaku tidak jujur akibat adanya kesempatan atau keputusan perilaku individu lain (Valle dan Ploner, 2017). Penelitian terdahulu oleh Rahmawati dan Aryani (2019) menyatakan bahwa senjangan anggaran lebih besar terjadi akibat pengaruh rekan yang tidak jujur daripada rekan yang jujur di bawah kondisi asimetri informasi. Maka berdasarkan penjelasan diatas, hipotesis yang diberikan adalah:

$\mathrm{H}_{1}$ : Diduga kejujuran pengelola anggaran berpengaruh negatif terhadap senjangan anggaran

\subsection{Penghargaan Moneter dan Non Moneter}

Menurut Burgess dan Ratto (2003) dalam Waqas (2014), penghargaan non moneter sangat membantu sebagai bentuk pengakuan terhadap karyawan dan pengakuan tersebut 
merupakan alat motivasi bagi karyawan dan mengarah pada keterlibatan kerja. Penghargaan moneter adalah penghargaan yang diberikan perusahaan kepada karyawan, untuk meningkatkan kepuasan secara langsung terhadap karyawan. Tujuan dari penghargaan adalah untuk memaksimalkan pengaruh positif bahwa beragam penghargaan dapat menghadirkan motivasi, keterikatan kerja, komitmen organiasi dan kepuasan kerja (Kimutai dan Sakataka, 2015).

Sistem penganggaran jika dihubungkan dengan sistem penghargaan berpotensi meningkatkan senjangan anggaran. Penghargaan yang digunakan dalam penelitian ini adalah penghargaan moneter dan non moneter. Penghargaan tersebut cenderung mengendalikan perilaku bawahan dengan membuatnya memenuhi target untuk memaksimalkan penghargaan. Penghargaan yang tergantung pada penyelesaian kinerja tersebut cenderung untuk merusak motivasi intrinsik. Penelitian yang dilakukan oleh Ardiyani (2017) yang menyatakan bahwa penghargaan (reward) berpengaruh terhadap senjangangan anggaran. Berdasarkan pernyataan dan penelitian sebelumnya, maka peneliti merumuskan hipotesis sebagai berikut: $\mathrm{H}_{2}$ : Diduga penghargaan moneter dan non moneter berpengaruh terhadap senjangan anggaran

\section{Metode Penelitian}

Peneliti menggunakan analisis data kuantitatif berupa kuesioner yang disebarkan kepada responden sebagai sampel dalam penelitian. Kuesioner disusun dengan menggunakan skala likert dengan pernyataan tentang sikap seseorang terhadap sesuatu. Populasi dalam penelitian ini yaitu karyawan PT. Riau Abdi Sentosa (Mayora Group) dan CV. Bintang Terang. Sampel dalam penelitian ini yaitu 51 karyawan yang bekerja pada perusahaan PT. Riau Abdi Sentosa (Mayora Group) dan CV. Bintang Terang. Metode pemilihan sampel didasarkan pada metode purposive sampling (Kuncoro, 2013). Kriteria dalam pengambilan sampel penelitian ini yaitu karyawan yang telah bekerja \pm 3 tahun dan karyawan yang memiliki jabatan sebagai administrasi dan accounting. Pengujian hipotesis dalam penelitian ini menggunakan analisis regresi linear berganda.

Variabel dalam penelitian ini diukur menggunakan skala likert 5 poin. Variabel senjangan anggaran menggunakan referensi kuisioner Amira (2019), kejujuran pengelola anggaran dari instrumen Anggraeni (2015), dan variabel penghargaan moneter dan non moneter dari instrumen Sulhi (2017) (lihat tabel 1 .

Tabel 1. Definisi Operasional Variabel

\begin{tabular}{clrl}
\hline Variabel & \multicolumn{2}{l}{ Definisi Operasional } & \multicolumn{1}{c}{ Indikator } \\
\hline Senjangan & \multicolumn{2}{c}{ Senjangan anggaran } & 1. Standar yang \\
Anggaran & yaitu perbedaan atau & digunakan \\
(Y) & selisih antara sumber & dalam \\
& daya yang sebenarnya & anggaran \\
& di butuhkan untuk & 2. Keterbatansan \\
& melaksanakan sebuah & jumlah \\
& pekerjaan dengan & anggaran \\
& sumber daya yang & 3. Target \\
& diajukan & dalam & anggaran yang \\
& anggaran & & dicapai \\
& (Amira, 2019) & 4. Sasaran dalam \\
& & anggaran.
\end{tabular}

(Amira, 2019)

\begin{tabular}{|c|c|}
\hline $\begin{array}{l}\text { Kejujuran } \\
\text { Pengelola } \\
\text { Anggaran } \\
\text { (X1) }\end{array}$ & $\begin{array}{lll}\text { Kejujuran merupakan } & \text { 1. } & \text { Bertekad } \\
\text { investasi yang sangat } & \text { melakukan } \\
\text { berharga, } & \text { karena } & \text { sesuatu } \\
\text { dengan kejujuran akan } & \text { kebenaran } \\
\text { sangat memberikan } & 2 . \text { Berbicara } \\
\text { manfaat bagi diri kita } & \text { dengan jujur } \\
\text { baik sekarang maupun } & \text { 2. Mengakui } \\
\text { di waktu yang akan } & \text { kesalahan } \\
\text { datang (Anggraeni, } & \text { sendiri } \\
\text { 2015). } & & \text { (Anggraeni, } \\
& & \text { 2015) }\end{array}$ \\
\hline $\begin{array}{l}\text { Penghargaan } \\
\text { Moneter Dan } \\
\text { Non Moneter } \\
\text { (X2) }\end{array}$ & $\begin{array}{ll}\begin{array}{l}\text { Penghargaan ekstrinsik } \\
\text { juga dikenal sebagai }\end{array} & \text { 2. Baji } \\
\text { keuangan atau } & \text { (Sulhi, 2017) } \\
\text { berwujud atau moneter } & \\
\text { sebagian besar bersifat } & \text { 1. Prestasi } \\
\text { finansial. } & \begin{array}{l}\text { 2. Pujian dari } \\
\text { atasan }\end{array} \\
\text { (Sulhi, 2017) } & \text { (Sulhi, 2017) } \\
\begin{array}{l}\text { Penghargaan non } \\
\text { moneter merupakan } \\
\text { apresiasi yang }\end{array} \\
\begin{array}{l}\text { diberikan oleh } \\
\text { perusahaan ketika }\end{array} \\
\begin{array}{l}\text { karyawan berhasil } \\
\text { mencapai target }\end{array} \\
\begin{array}{l}\text { anggaran. } \\
\text { (Sulhi, 2017) }\end{array}\end{array}$ \\
\hline
\end{tabular}


4. Hasil Penelitian dan Pembahasan

\subsection{Uji Statistik Deskriptif}

Menurut Ghozali (2013), uji statistik deskriptif memberikan gambaran atau deskripsi suatu data dilihat dari mean, minimum, maximum, dan standard deviation. Tabel 2 menampilkan hasil uji statistik deskriptif variabel yang diteliti.

Tabel 2. Statistik Deskriptif

\begin{tabular}{lccccc}
\hline & N & Min & Max & Mean & Std. dev \\
\hline $\begin{array}{l}\text { Senjangan Anggaran } \\
\text { Kejujuran Pengelola }\end{array}$ & 51 & 10 & 24 & 19.76 & 2.833 \\
$\begin{array}{l}\text { Anggaran } \\
\begin{array}{l}\text { Penghargaan Moneter } \\
\text { dan Non Moneter }\end{array}\end{array}$ & 51 & 37 & 55 & 45.47 & 3.977 \\
Valid N (listwise) & 51 & & & & \\
\hline
\end{tabular}

Sumber : Data Diolah, 2021

Berdasarkan tabel 2, dapat dijelaskan bahwa variabel senjangan anggaran berjumlah 51 sampel, yang memiliki nilai minimum sebesar 10, nilai maksimum 24 dan nilai ratarata (mean) sebesar 19.76 dengan standar deviasi sebesar 2.833. Selanjutnya, variable kejujuran pengelola anggaran memiliki nilai minimum sebesar 27, nilai maksimum 35 dan nilai rata-rata (mean) sebesar 30.84 dengan standar deviasi sebesar 1.943. Terakhir, variabel penghargaan moneter dan non moneter menunjukan nilai minimum 37 dan nilai maksimum 55 dengan nilai rata-rata (mean) 45.47 dan standar deviasi 3.977

\subsection{Uji Realibilitas Data}

Suatu variabel dikatakan reliabel jika memberikan nilai Cornbach Alpha > 0,60 (Afiani, 2010). Hasil pengujian reliabilitas data pada tabel 3 menunjukkan bahwa nilai Cronbach Alpha dari setiap variabel lebih besar dari 0,60 yang berarti bahwa kuesioner yang merupakan indikator-indikator dari variabel tersebut reliabel.

Tabel 3. Hasil Uji Reliabilitas

\begin{tabular}{lcrc}
\hline \multicolumn{1}{c}{ Variabel } & Cronbach Alpha & $\mathrm{N}$ & Ket \\
\hline $\begin{array}{l}\text { Senjangan Anggaran } \\
\text { Kejujuran Pengelola }\end{array}$ & 0.678 & 51 & Reliabel \\
$\begin{array}{l}\text { Anggaran } \\
\begin{array}{l}\text { Penghargaan Moneter } \\
\text { dan Non Moneter }\end{array}\end{array}$ & 0.613 & 51 & Reliabel \\
\hline Sumber : Data Dion & 0.721 & 51 & Reliabel \\
\hline
\end{tabular}

Sumber : Data Diolah, 2021

\subsection{Uji Validitas}

Menurut Afiani (2010), uji validitas dilakukan dengan tujuan untuk mengetahui sejauh mana ketepatan dan kecermatan suatu alat ukur dalam menentukan fungsi pengukurannya. Pendekatan yang dilakukan dengan menghitung korelasi antara skor masing-masing butir pertanyaan dengan skor total yang diteliti menggunakan teknik korelasi product momment dari Pearson correlations. Paerson correlation dikatakan positif dan signifikan pada level 0,05.

Uji tersebut dilakukan dengan membandingkan nilai $r$ hitung dengan $r$ tabel untuk degree of freedom $(\mathrm{df})=\mathrm{n}-2$, dalam hal ini adalah jumlah sampel. Pada penelitian ini, jumlah sampel $(\mathrm{n})=51$ dan besarnya " $\mathrm{df}$ " dapat dihitung $51-2=49$ dengan "df" $=49$ dan didapat $r$ tabel $=0.2759$. Dari hasil uji validitas menujukkan bahwa masing-masing item variabel memiliki nilai $r_{\text {hitung }}>r_{\text {tabel }}$ dengan tingkat signifikan kurang dari 0,05 yang berarti butir pernyataannya semua variabel penelitian ini di nyatakan valid. Hasil pengujian validitas data untuk pernyataan dapat dilihat pada tabel 4 .

Tabel 4. Hasil Uji Validitas Data

\begin{tabular}{lcccc}
\hline \multicolumn{1}{c}{ Variabel } & Item & $\mathbf{R}_{\text {hitung }}$ & $\mathbf{R}_{\text {tabel }}$ & Ket \\
\hline Senjangan & Y1.1 & 0.425 & 0,2759 & Valid \\
Anggaran & Y1.2 & 0.594 & 0,2759 & Valid \\
& Y1.3 & 0.667 & 0,2759 & Valid \\
& Y1.4 & 0.741 & 0,2759 & Valid \\
& Y1.5 & 0.644 & 0,2759 & Valid \\
& Y1.6 & 0.640 & 0,2759 & Valid \\
\hline Kejujuran & X1.1 & 0.491 & 0,2759 & Valid \\
Pengelola & X1.2 & 0.643 & 0,2759 & Valid \\
Anggaran & X1.3 & 0.556 & 0,2759 & Valid \\
& X1.4 & 0.554 & 0,2759 & Valid \\
& X1.5 & 0.519 & 0,2759 & Valid \\
& X1.6 & 0.634 & 0,2759 & Valid \\
& X1.7 & 0.463 & 0,2759 & Valid \\
\hline Penghargaan & X2.1 & 0.569 & 0,2759 & Valid \\
Moneter dan & X2.2 & 0.406 & 0,2759 & Valid \\
Non Moneter & X2.3 & 0.546 & 0,2759 & Valid \\
& X2.4 & 0.568 & 0,2759 & Valid \\
& X2.5 & 0.401 & 0,2759 & Valid \\
& X2.6 & 0.395 & 0,2759 & Valid \\
& X2.7 & 0.342 & 0,2759 & Valid \\
& X2.8 & 0.508 & 0,2759 & Valid \\
& X2.9 & 0.579 & 0,2759 & Valid \\
& X2.10 & 0.566 & 0,2759 & Valid \\
& X2.11 & 0.572 & 0,2759 & Valid \\
& X2.12 & 0.483 & 0,2759 & Valid \\
\hline & 2021 & & & \\
& & & & \\
& & &
\end{tabular}

Sumber : Data Diolah, 2021

\subsection{Uji Asumsi Klasik}

Pengujian asumsi klasik sebagai syarat pemenuhan dalam analisis regresi berganda dilakukan dengan berbagai uji diantaranya adalah uji normalitas, uji multikolinieritas, dan uji heteroskedastisitas. 
Hasil uji normalitas pada tabel 5, menunjukkan bahwa nilai signifikan sebesar 0,200>0,05 dan dapat disimpulkan bahwa data berdistribusi normal sehingga dapat diuji dengan analisa regresi.

Tabel 5. Hasil Uji Normalitas

\begin{tabular}{|c|c|c|}
\hline & & $\begin{array}{c}\text { Unstandardized } \\
\text { Residual }\end{array}$ \\
\hline $\mathrm{N}$ & & 51 \\
\hline Normal & Mean & . 0000000 \\
\hline Parameters ${ }^{\mathrm{a}, \mathrm{b}}$ & $\begin{array}{l}\text { Std. } \\
\text { Deviation }\end{array}$ & 1.99027962 \\
\hline Most Extreme & Absolute & .081 \\
\hline Differences & Positive & .052 \\
\hline & Negative & -.081 \\
\hline Kolmogorov-S & lov Z & .081 \\
\hline Asymp. Sig. (2 & & 0.200 \\
\hline
\end{tabular}

Selanjutnya, berdasarkan tabel 6 menampilkan hasil uji multikolinieritas dan terlihat bahwa setiap variabel memiliki nilai tolerance $>0,10$ dan nilai $\mathrm{VIF}<10$, maka hal itu dinyatakan tidak terdapat multikolinearitas antar variabel bebas dalam model regresi.

Tabel 6. Uji Multikolinearitas

\begin{tabular}{lcc}
\hline \multicolumn{1}{c}{ Model } & \multicolumn{2}{c}{ Collinearity Statistics } \\
\cline { 2 - 3 } & Tolerance & VIF \\
\hline (Constant) & 0.798 & 1.254 \\
$\begin{array}{l}\text { Kejujuran Pengelola } \\
\text { Anggaran }\end{array}$ & 0.798 & 1.254 \\
$\begin{array}{l}\text { Penghargaan Moneter Dan } \\
\text { Non Moneter }\end{array}$ & & \\
\hline Sumber : Data Diolah, 2021 & &
\end{tabular}

Terakhir, hasil uji heterokedastisitas mengunakan uji glejser pada tabel 7 diperoleh nilai signifikan variabel kejujuran pengelola anggaran sebesar 0,645, dan nilai signifikan penghargaan moneter dan non moneter sebesar 0,482. Hasil tersebut berada diatas 0,05 sehingga dapat diartikan bahwa tidak terdapat heterokedastisitas dalam model regresi penelitian ini.

Tabel 7. Uji Heterokedastisitas

\begin{tabular}{|c|c|c|c|c|}
\hline \multirow[t]{2}{*}{ Model } & \multicolumn{2}{|c|}{$\begin{array}{l}\text { Unstandardized } \\
\text { Coefficients }\end{array}$} & \multirow[t]{2}{*}{$\mathrm{t}$} & \multirow[t]{2}{*}{ Sig. } \\
\hline & B & Std. Error & & \\
\hline (Constant) & 1.726 & 2.812 & .614 & .542 \\
\hline $\begin{array}{l}\text { Kejujuran Pengelola } \\
\text { Angoaran }\end{array}$ & .045 & .098 & .464 & .645 \\
\hline $\begin{array}{l}\text { Penghargaan } \\
\text { Moneter \& Non } \\
\text { Moneter }\end{array}$ & -.034 & .048 & -.708 & .482 \\
\hline
\end{tabular}

\subsection{Analisis Regresi Linear Berganda}

Ringkasan hasil uji regresi linear berganda dengan menggunakan program SPSS versi 23 ditunjukkan pada tabel 8 .

Tabel 8. Analisis Regresi Berganda

\begin{tabular}{lcccc}
\hline & \multicolumn{4}{c}{ Unstandardized } \\
Model* & Coefficients & & \multirow{2}{*}{ Sig. } \\
\cline { 2 - 3 } & $\mathrm{B}$ & $\begin{array}{c}\text { Std. } \\
\text { Error }\end{array}$ & & \\
\hline $\begin{array}{l}\text { (Constant) } \\
\text { Kejujuran }\end{array}$ & 20.325 & 4.773 & 4.258 & .000 \\
$\begin{array}{l}\text { Pengelola } \\
\text { Anggaran }\end{array}$ & -.815 & .166 & -4.921 & .000 \\
$\begin{array}{l}\text { Penghargaan } \\
\text { Moneter dan } \\
\text { Non Moneter }\end{array}$ & .540 & .081 & 6.680 & .000 \\
\hline *Dependent Variable: Senjangan Anggaran &
\end{tabular}

Berdasarkan tabel 8 dapat dilihat bahwa hipotesis pertama yang menguji pengaruh variabel kejujuran pengelola anggaran terhadap senjangan anggaran memiliki nilai $t_{\text {hitung }}$ yaitu $-4,921$ dengan nilai signifikansi 0,000. Artinya variabel kejujuran pengelola anggaran $\left(\mathrm{X}_{1}\right)$ berpengaruh signifikan negatif terhadap senjangan anggaran (Y). Maka dapat di simpulkan bahwa hipotesis pertama diterima. Kemudian, hipotesis kedua yang menguji pengaruh penghargaan moneter dan non moneter terhadap senjangan anggaran memiliki nilai $t_{\text {hitung }}$ yaitu 6,680 dengan nilai signifikansi 0,000 . Artinya variabel penghargaan moneter dan non moneter $\left(\mathrm{X}_{2}\right)$ berpengaruh terhadap senjangan anggaran (Y). Maka dapat di simpulkan bahwa hipotesis kedua diterima.

Selanjutnya, penulis juga melakukan analisis tambahan dengan menguji secara terpisah jenis penghargaan moneter dan non moneter untuk melihat apakah ada perbedaan hasil jika jenis penghargaan yang diterima karyawan yang berbeda antara penghargaan moneter dan penghargaan non moneter. Hasil pengujian pada tabel 9 menujukkan adanya perbedaan hasil dimana penghargaan moneter memiliki nilai signifikansi sebesar 0,020 yang berarti bahwa penghargaan moneter berpengaruh signifikan positif terhadap senjangan anggaran. Sedangkan penghargaan non moneter memiliki nilai signifikansi 0.066 yang berarti bahwa penghargaan non moneter tidak memiliki pengaruh terhadap senjangan anggaran. 
Tabel 9. Hasil Uji Terpisah Penghargaan Moneter dan Non Moneter

\begin{tabular}{lccccc}
\hline Model & \multicolumn{3}{c}{$\begin{array}{l}\text { Unstandardized } \\
\text { Coefficients }\end{array}$} & $\mathrm{t}$ & Sig. \\
\cline { 2 - 4 } & $\mathrm{B}$ & Std. Error & & \\
\hline (Constant) & 3.398 & 4.052 & .839 & .406 \\
Penghargaan Moneter & .391 & .163 & 2.398 & .020 \\
$\begin{array}{l}\text { Penghargaan Non } \\
\text { Moneter }\end{array}$ & .328 & .175 & 1.879 & .066 \\
\hline
\end{tabular}

\subsection{Uji Koefisien Determinasi $\left(R^{2}\right)$}

Uji koefisien determinan dilakukan untuk mengukur kemampuan variabel independen dalam menjelaskan variabel dependen, nilai koefisien determinasi adalah antara nol dan satu. Jika nilai $\mathrm{R}^{2}$ kecil menandakan kemapuan variabel - variabel independen dalam mejelaskan variabel dependen amat terbatas. Nilai yang mendekati satu berarti variabel - variabel independen memberikan hampir semua informasi yang dibutuhkan memprediksi variasi variabel dependen (Sugiono, 2012). Berdasarkan tabel 10 dapat dilihat bahwa hasil uji koefisien determinasi $\left(\mathrm{R}^{2}\right)$ untuk nilai $\mathrm{R}$ Square sebesar 0,506. Hal ini menunjukkan bahwa $50,6 \%$ variabel senjangan anggaran dapat dijelaskan oleh variabel kejujuran pengelola anggaran serta penghargaan moneter dan non moneter. Sedangkan sisanya sebesar $49,4 \%$ senjangan anggaran dipengaruhi oleh variabel lain yang tidak diteliti dalam model ini.

Tabel 10. Uji Koefisien Determinasi $\left(\mathrm{R}^{2}\right)$

\begin{tabular}{lcccc}
\hline Model & $\mathrm{R}$ & $\begin{array}{c}\mathrm{R} \\
\text { Square }\end{array}$ & $\begin{array}{c}\text { Adjusted R } \\
\text { Square }\end{array}$ & $\begin{array}{c}\text { Std. Error of } \\
\text { the Estimate }\end{array}$ \\
\hline 1 & $.712^{\mathrm{a}}$ & .506 & .486 & 2.031
\end{tabular}

Sumber : Data Diolah, 2021

\subsection{Pembahasan}

\section{Pengaruh Kejujuran Pengelola Anggaran Terhadap Senjangan Anggaran}

Hasil penelitian mendukung hipotesis pertama (H1) yang menyatakan bahwa kejujuran pengelola anggaran berpengaruh signifikan negatif terhadap senjangan anggaran. Hal ini menunjukan bahwa semakin tinggi nilai kejujuran yang dimiliki oleh pihakpihak yang ikut berpartisipasi dalam penyusunan anggaran maka dapat membantu mengurangi praktik senjangan anggaran.

Temuan ini sesuai dengan teori yang dikembangkan oleh Milgram (1974) dalam Silva (2015), yang mengungkapkan bahwa bawahan yang mengalami obedience pressure dari atasan akan mengalami perubahan psikologis dari seseorang yang berperilaku otonomis menjadi perilaku agen. Hasil penelitian ini sejalan dengan penelitian yang dilakukan oleh Rahmawati dan Aryani (2019) yang menyatakan bahwa senjangan anggaran lebih besar terjadi akibat pengaruh rekan yang tidak jujur daripada rekan yang jujur di bawah kondisi asimetri informasi.

\section{Pengaruh Penghargaan Moneter Dan Non Moneter Terhadap Senjangan Anggaran}

Hasil penelitian mendukung hipotesis kedua (H2) yang menyatakan bahwa penghargaan moneter dan non moneter berpengaruh terhadap senjangan anggaran. Artinya bawahan cenderung mengajukan anggaran dengan merendahkan pendapatan dan menaikkan biaya dibandingkan dengan estimasi yang diajukan, sehingga target akan lebih mudah tercapai. Hal ini dilakukan untuk mendapatkan penghargaan atas target yang telah dicapai Namun demikian tingginya penghargaan moneter dan non moneter tidak selalu dapat menurunkan senjangan anggaran, karena adanya peluang yang besar serta kenyamanan posisi atau jabatan yang dimiliki. Hal ini dibuktikan dengan hasil nilai koefisien regresi yang positif.

Ketika dilakukan uji terpisah terhadap variabel penghargaan moneter dan non moneter. Variabel penghargaan moneter berpengaruh positif terhadap senjangan anggaran. Sedangkan variabel penghargaan non moneter tidak berpengaruh signifikan terhadap senjangan anggaran. Berdasarkan hasil kesimpulan jawaban responden penghargaan moneter memberikan pengaruh lebih besar dibandingkan penghargaan non moneter karena penghargaan (reward) yang di berikan perusahaan secara langsung kepada karyawan seperti uang, dapat meningkatkan kepuasan secara langsung terhadap karyawan karena uang dianggap bisa membantu pemenuhan kebutuhan dibandingkan dengan penghargaan non moneter yang diberikan perusahaan kepada individu seperti pujian dari atasan dan rekan kerja, ruang kerja yang memiliki lokasi dan fasilitas istimewa, tempat parkir khusus, gelar istimewa dan sekretaris pribadi.

Sesuai dengan teory keagenan dikemukakan oleh Jensen \& Meckling (1976) 
yang menjelaskan adanya perbedaan kepentingan antara manajer atas dengan karyawannya. Manajer atas tentunya menginginkan pencapaian target yang bagus untuk perusahaan untuk meningkatkan kualitas perusahaan yang lebih baik, untuk itu manajer atas memberikan penghargaan (reward) bila karyawannya dapat mencapai target yang ditetapkan, namun dibalik itu karyawan justru memiliki kepentingan untuk mencapai penghargaan (reward) yang tinggi tanpa mungkin memperhatikan target yang disepakati sebelumnya.

Hasil penelitian ini sejalan dengan penelitian yang dilakukan oleh Ardiyani (2017) yang menyatakan bahwa penghargaan (reward) berpengaruh terhadap senjangangan anggaran. Hasil penelitian ini juga didukung oleh Desmayani dan Suardhika (2016) menunjukkan bahwa penghargaan (reward) berpengaruh terhadap budgetary slack. Hasil penelitian ini juga didukung oleh Rahmawati dan Aryani (2019) yang menjelaskan bahwa penghargaan non moneter tidak berpengaruh terhadap senjangan anggaran, karena penghargaan non moneter yang diberikan tergantung pada penyelesaian tugas dan dinilai dapat merusak motivasi intrinsik yang ada dalam diri seseorang, sehingga penghargaan ini sebaiknya dikurangi atau ditiadakan.

\section{Kesimpulan}

Variabel kejujuran pengelola anggaran berpengaruh negatif terhadap senjangan anggaran. Hal ini menunjukkan senjangan anggaran lebih besar terjadi akibat tidak jujurnya seorang pengelola anggaran, daripada karyawan yang jujur, sehingga nilai kejujuran yang dimiliki setiap karyawan dapat membantu mengurangi praktik senjangan anggaran. Variabel penghargaan moneter dan non moneter berpengaruh terhadap senjangan anggaran. Hal dikarenakan penghargaan yang di berikan tidak selalu dapat menurunkan senjangan anggaran, karena adanya peluang yang besar serta kenyamanan atau posisi jabatan yang di miliki setiap karyawan, sehingga bawahan cenderung mengajukan anggaran dengan merendahkan pendapatan dan menaikkan biaya dibandingkan dengan estimasi yang diajukan, sehingga target akan lebih mudah tercapai. Hal ini dilakukan untuk mendapatkan penghargaan atas target yang telah dicapai. Variabel kejujuran pengelola anggaran, penghargaan moneter dan non moneter secara bersama sama berpengaruh terhadap senjangan anggaran. Hal ini dikarenakan keinginan untuk jujur merupakan karakteristik individu oleh karena itu bawahan menginginkan untuk jujur dalam menetapkan anggaran serta penghargaan diberikan agar mereka tetap mempertahankan kinerja mereka yang baik, karena tidak menutup kemungkinan karyawan memperbaiki kinerjanya dengan harapan memperoleh penghargaan dari perusahaan sehingga dapat memperbaiki taraf hidupnya kearah yang lebih baik lagi.

Berdasarkan penelitian yang dilakukan, terdapat beberapa keterbatasan penelitian. Pertama, adanya keterbatasan penelitian dengan menggunakan kuesioner yaitu terkadang jawaban yang diberikan oleh sampel tidak menunjukkan keadaan sesungguhnya. Oleh karena itu, penelitian selanjutnya bisa menggunakan metode wawancara untuk meningkatkan sikap kepedulian dan keseriusan responden dalam menjawab semua pernyataan-pernyataan yang ada Kedua, peneliti hanya berfokus pada faktor kejujuran pengelola anggaran, penghargaan moneter dan non moneter. Tidak menutup kemungkinan masih ada faktor - faktor lainnya yang dapat mempengaruhi senjangan anggaran. Adanya keterbatasan penelitian tentang pengaruh kejujuran pengelola anggaran terhadap senjangan anggaran dikarenakan referensi untuk variabel kejujuran pengelola anggaran sangat sedikit. Penelitian ini memberikan implikasi bahwa organisasi harus selalu meningkatkan kejujuran dalam pengelolaan anggaran dan memberikan penghargaan (reward) apabila karyawannya dapat mencapai target yang diharapkan.

\section{Daftar Pustaka}

Afiani, D., N. (2010). Pengaruh Partisipasi Anggaran, Penekanan Anggaran Dan Asimetri Informasi Terhadap Senjangan Anggaran Pada Instansi Pemerintah Daerah (Studi Pada Pemerintah Daerah Kabupaten Semarang). Skripsi Universitas Diponegoro. Semarang.

Agustina. (2018). Pengaruh Obedience Pressure Dan Organizational Commitment 
Terhadap Penciptaan Budgetary Slack Dengan Pertimbangan Etika Sebagai Variabel Moderating (Studi Kasus pada OPD Kabupaten Wajo) Skripsi. Skripsi Universitas Islam Negeri Alauddin. Makassar.

Amira, R. Y. (2019). Pengaruh Penganggaran Partisipatif, Self Esteem, Locus Of Control, Kapasitas Individu Dan Komitmen Organisasi Terhadap Kesenjangan Anggaran (Budgetary Slack) (Studi Empiris Pada Organisasi Perangkat Daerah (Dinas Dan Badan) Kabupaten Kampar). Skripsi UIN Suska Riau. Pekanbaru.

Anggraeni, A. (2015). Pengaruh Self Esteem, Etika, Skema Kompensasi Slack Inducing Dan Truth Inducing Serta Asimetri Informasi Terhadap Budgetary Slack: Studi Eksperimen Pada Konteks Penganggaran Partisipatif. Skripsi Universitas Negeri Yogyakarta. Yogyakarta.

Ardiyani, F. (2017). Pengaruh Self Efficacy, Reward And Punishment, Dan Asimetri Informasi Terhadap Budgetary Slack: Studi Eksperimen Pada Konteks Penganggaran Partisipatif. Jurnal Nominal, VI(1).

Azmi, Z., Nisa, O. H., \& Suci, R. G. (2021). Factors Affecting The Tendency Of Accounting Fraud In Hospitals In Pekanbaru City. Bilancia: Jurnal Ilmiah Akuntansi, 5 (1), (1-14).

Biantara, A. A. A., \& Putri, IG. A. M. A. D. (2014). Pengaruh Kejelasan Sasaran Anggaran, Etika, Dan Kepercayaan Diri Pada Senjangan Anggaran. E-Jurnal Akuntansi Universitas Udayana 9(2): 38591.

Bitlinandas, F. (2018). Pengaruh partisipasi anggaran, penekanan anggaran dan asimteri informasi terhadap budgetary slack degan ketidakpastian lingkungan sebagai variable moderasi. Jom Feb 1(1): $1-15$.

Brigham, E. F., \& Gapenski, I. C. (1996). Intermediate Financial Managememt (Fifth Edit). The Dryden Press. New York.

Desmayani, N. M. M. R, \& Suardhika, I. M. S. (2016). Pengaruh Penganggaran Partisipatif, Locus of Control, Dan
Pemberian Reward Terhadap Budgetary Slack. E-Jurnal Akuntansi Universitas Udayana 16 (2).

Ghozali, I. (2013). Aplikasi Analisis Multivariate dengan Program IBM SPSS 19, Badan Penerbit Universitas Diponegoro. Semarang.

Hapsari, E. D., \& Arifin, A. (2016). Pengaruh Partisipasi Anggaran, Asimetri Informasi, Komitmen Organisasi, Dan Penekanan Anggaran Terhadap Slack Anggaran Dengan Kompleksitas Tugas Sebagai Variabel Moderasi (Studi Kasus Pada Bank Mega Syariah Cabang Solo). Tesis Universitas Muhammadiyah Surakarta. Solo.

Jensen, M. C., \& Meckling, W. H. (1976). Theory of the firm: Managerial behavior, agency costs and ownership structure. Journal of Financial Economics, 3(4), 305-360.

Kimutai, K. A., \& Sakataka, W. (2015). Effect of reward on employee engagement and commitment at Rift Valley Bottlers Company. International Academic Journal of Human Resource and Business Administration. 1(5), 36-54.

Kuncoro, M. (2013). Metode Riset untuk Bisnis dan ekonomi. Penerbit Erlangga. Jakarta.

Rahmawati, I. E., \& Aryani. (2019). Pengaruh Kejujuran Rekan Dan Penghargaan Non Moneter Pada Senjangan Anggaran. Jurnal Akuntansi dan Keuangan Indonesia 16(1): 17-34.

Oksanda, B. (2015). Pengaruh Partisipasi Penyusunan Anggaran Dan Kejelasan Sasaran Anggaran Terhadap Senjangan Anggaran Instansi Pemerintah Daerah Dengan Asimetri Informasi, Group Cohesiveness, Budaya Organisasi Dan Kecukupan Anggaran Sebagai Variabel Moderasi (Studi Empiris. E-Jurnal Akuntansi 2(2).

Setyobudi, B., Herwiyanti, E., Azhar, S., \& Rafinda, A. (2017). Pengaruh Insentif Moneter Dan Non-Moneter terhadap Kinerja Individual. Sustainable Competitive Advantage 7: 592-602.

Silva, E. G. A. V. D. (2015). Tekanan Ketaatan, Kompleksitas Tugas, Monitoring: Pengaruhnya terhadap 
Kecenderungan Kecurangan Akuntansi (Studi pada staf Kementerian Keuangan Republik Dekmokratik Timor-Leste). Tesis Universitas Kristen Satya Wacana.

Sugiono. (2012). Metode Penelitian Kuantitatif Kualitatif. CV Alfabeta. Bandung.

Sugianto, Azmi, Z., \& Ramashar, W. (2020). Determinants Of Budgetary Slack. Jurnal Ilmiah Akuntansi. 4(3), 262-270.

Sulhi, I. R. (2017). Pengaruh kompensasi finansial dan non finansial terhadap kinerja karyawan rumah sakit mata $d r$. Yap yogyakarta. Skripsi Universitas Negeri Yogyakarta. Yogyakarta.

Supanto. (2010). Analisis Pengaruh Partisipasi Penganggaran Terhadap Budgetary Slack dengan Informasi Asimetri, Motivasi, Budaya Organisasi sebagai Pemoderasi (Studi Kasus pada Politeknik Negeri Semarang). Tesis Universitas Diponegoro. Semarang.
Tjandra, M. (2008). Pengaruh Partisipasi Dalam Penyusunan Anggaran Terhadap Kinerja Manajerial Dengan Reward Sebagai Variabel Moderating Pada Asian Agri Group. Tesis Sekolah Pascasarjana Universitas Sumatera Utara. Medan.

Valle, N. D., \& Ploner, M. (2017). Reacting to Unfairness: Group Identity and Dishonest Behavior. Games, 8(3), 28.

Waqas, Z. (2014). The Effect of Monetary and Non-Monetary Rewards on Employee Engagement and Firm Performance. European Journal of Business and Management 31(5): 2-12.

Yandriyan. (2019). Pengaruh Partisipasi Anggaran, Komitmen Organisasi, Kapasitas Individu, Kejelasan Sasaran Anggaran, Dan Ketidakpastian Lingkungan Terhadap Senjangan Anggaran. Rabit: Jurnal Teknologi dan Sistem Informasi Univrab 1(1). 